\title{
Advertising, Individual Consumption Levels, and the Natural Environment, 1900-2000
}

\author{
Robert J. Brulle, Drexel University \\ Lindsay E. Young, University of Utah
}

\begin{abstract}
One central determinant of global environmental change is the continued expansion of personal consumption levels. In order to more fully understand the relationship between consumption and environmental degradation, the determinants of consumption must first be identified. Prior research in this area has focused on economic factors, primarily personal disposable income and population demographic characteristics. The role of cultural factors, including advertising, has been actively mentioned in theoretical analyses of the driving forces of individual consumption. However, this has not been empirically tested. In this article, we conduct an analysis of the impact of advertising on consumption levels in the United States. We start with a theoretical discussion of the literature on advertising and consumption. Based on this literature, we establish three hypotheses regarding the relationship between advertising expenditure and personal consumption. These hypotheses are then tested using time series analysis over the time period 1900-2000. The results show that advertising significantly impacts overall consumption and that these effects vary by type of consumption. We conclude with a discussion of the implications of this analysis for further research into the driving forces of global environmental change.
\end{abstract}

At the beginning of the twenty-first century, environmental degradation continues apace. There is accumulating evidence that human activities have now moved beyond the carrying capacity of the earth's ecosystem (Hansen 2005; Vitousek et al. 1997). The overall result of this process is projected to be the irreversible degradation of many of the global ecosystems and the extinction of many species of plants and animals. These ecological problems lead to a severe cumulative adverse effect, not only for the other beings with whom we share the earth, but also for human health and well-being (Chivian et al. 1993; McCally 2002).

One central factor of global environmental change is the continued expansion of consumption levels. The relationship between individual consumption and environmental degradation has been well recognized for over half a century. In 1953, Ordway (1953) argued that the continued expansion of resource use would eventually lead to the exhaustion of the earth's resources and the consequent collapse of our society. This sentiment was echoed by Galbraith (1958:92), who in analyzing our expanding resource consumption, noted, "If we are concerned 
about our great appetite for materials, it is plausible to seek to increase the supply, to decrease waste, to make better use of the stocks that are available, and to develop substitutes. But what of the appetite itself? Surely this is the ultimate source of the problem." He then argues that a major contributor in increasing consumption is the "mass pressures of modern merchandising" (Galbraith 1958:99).

Consumption forms one of the central components of the famous IPAT model. In this model, A which stands for Affluence, is a measure of individual per capita consumption. Recently, there has been an expansion of the empirical analyses of the driving forces of global environmental change based on the IPAT model, in the form of STIRPAT (Stochastic Impacts by Regression on Population, Affluence and Technology) analyses (York, Rosa, and Dietz 2003). However, in none of this research is there any empirical analyses of the social or economic forces that drive increased individual consumption. This absence of the analysis of the driving forces of consumption has been noted by the National Research Council:

Critics of "consumer society" point to advertising and the mass media as drivers of materialist attitudes and desires and argue that these forces and others are driving the emerging middle classes in many developing countries to emulate North American styles of consumption. These plausible arguments have not yet been supported by careful quantitative studies of the relevant social forces, attitudes, and behaviors." (NRC 1999:327)

The aim of this article is to initiate a research effort into this issue. We conduct an analysis of the impact of advertising on consumption levels in the United States. In Part I, we provide an overview of the relationship between environmental degradation, material use, and consumption. This theoretical discussion frames our analysis of the driving forces behind individual consumption. In Part II, we provide an overview of the economic literature regarding the determinants of personal consumption. Part III then expands the discussion to the role of advertising in the social construction of needs and commoditization of life and how this results in corporate driven patterns of status consumption. We then test the impact of advertising on personal consumption levels. Part IV describes the methods used in this empirical analysis. The results are then presented in Part V. We then conclude with a discussion of the importance of advertising in driving individual consumption levels and outline some directions for further research.

\section{Environment Degradation and Consumption}

The relationship between environmental impact and consumption has been formalized in the widely used IPAT model (Chertow 2001). Originally developed in 1971 (Erlich and Holdren 1971), the IPAT model "represents the efforts of population biologists, ecologists, and environmental scientists to formalize the relationship between population, human welfare, and environmental impacts" (Dietz and Rosa 1994:278). The IPAT model postulates a causal sequence of the 
Total U.S. Consumption 1900-2000

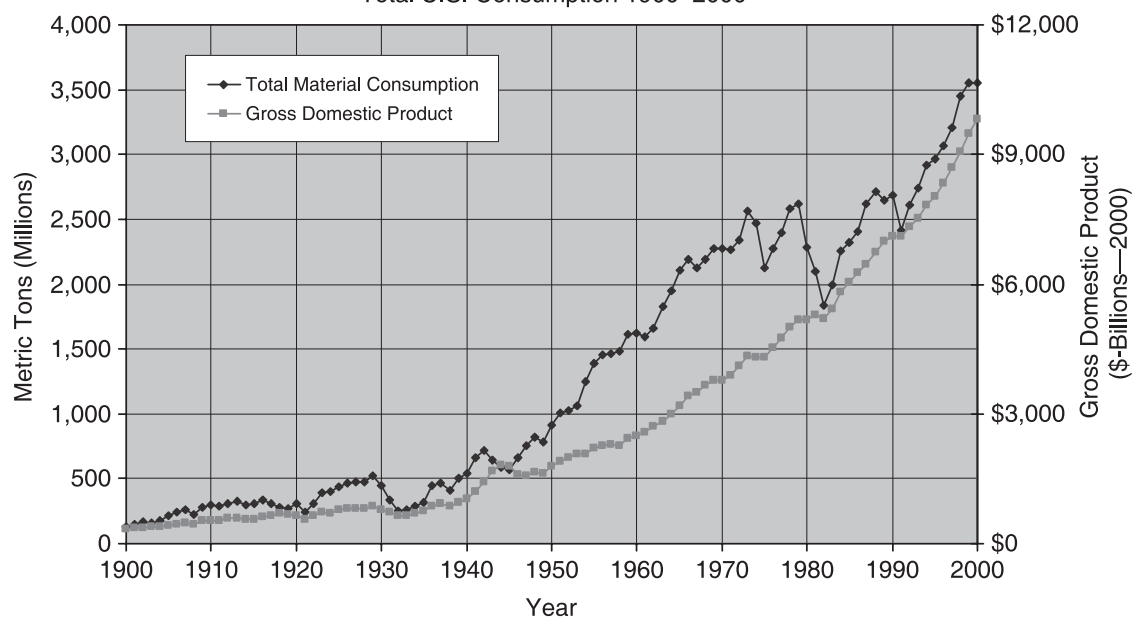

\section{Figure 1}

Total U.S. Consumption, 1900-2000

impacts of human activity on the natural environment. Environmental Impacts (I) are seen as a function of three variables: (1) P-Population, (2) A-Affluence Level, and (3) T-Technological Development. In these analyses, the technology variable is usually omitted and the core of the analysis rests on the relationship between increases in population and affluence, which is usually measured as the level of gross domestic product (GDP) per capita. The dependent variable is a measure of total withdrawals from the natural environment, which are typically measured by environmental economists using the concept of materials flow. To calculate the overall environmental impact of the economy on the natural environment, the total weight of natural resources withdrawn for economic use is calculated through the conversion of items such as crop yields to its total weight. These analyses clearly show that increased population and affluence levels lead to increased withdrawals from the natural environment and increased environmental degradation (Manno 1999; Wackernagel and Rees 1996). This measure for the U.S. economy is shown in Figure 1. As this graph shows, the total withdrawals from the natural environment over the twentieth century increased by a factor of over 26-fold, from 134 million metric tons in 1900 to over 3.5 billion metric tons in 2000. At the same time, total gross domestic production increased (in constant $\$ 2000$ ) by a factor of nearly 30-fold, from $\$ 328$ billion in 1900 to $\$ 9,817$ billion in 2000 . During the same period, population increased by a factor of 3.6, from 76 million in 1900 to 276 million in 2000. So while it is clear that increased population has had some effect on the increased 


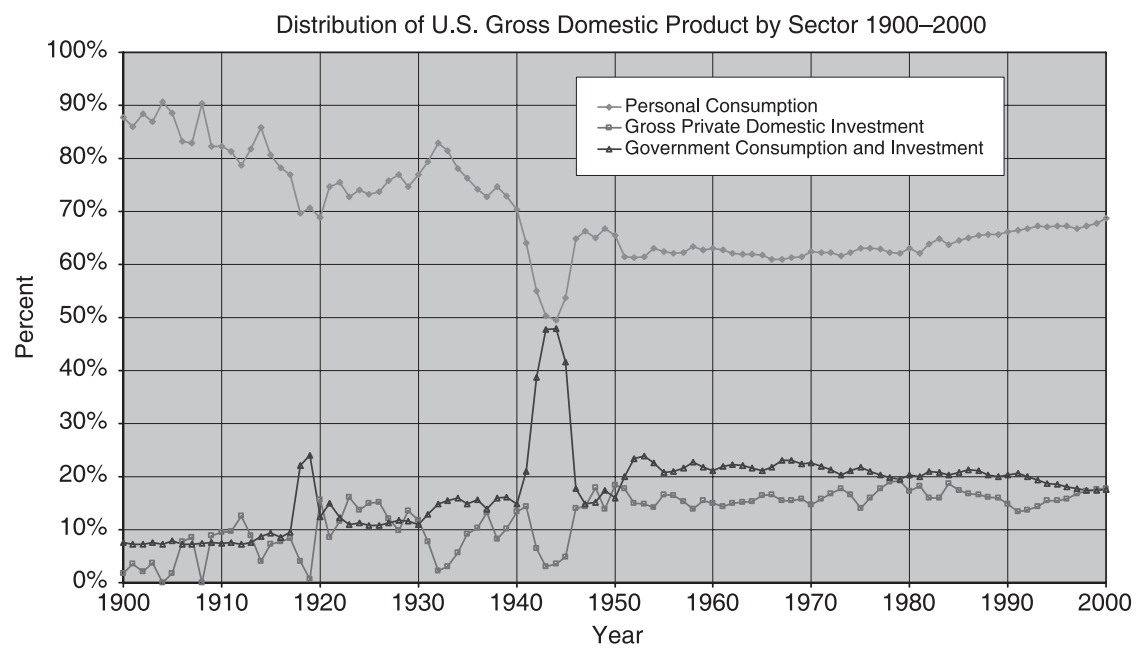

Figure 2

Consumption by Type, 1900-2000

environmental withdrawals of the U.S. economy from the natural environment, one of the major driving forces for the U.S. economy is the substantial increase in affluence levels.

The measure of affluence, that is, GDP is comprised of three different components: (1) Personal Consumption, (2) Government Consumption and Investment, and (3) Gross Private Domestic Investment. The percentages of each component over the course of the twentieth century is shown in Figure 2. As this graph shows, individual consumption is the largest single factor of overall consumption. However, there are significant changes in consumption levels due to government policies, including the initiation of the New Deal and during both World War I and II. The implication of this distribution is that there are different factors that determine the overall levels of consumption in any society and thus an analysis of the driving forces of consumption need to disaggregate its components and develop empirical models for each type of consumption.

This distribution of consumption by sectors has not been taken into account in the examination of the driving forces of environmental change. This research has been primarily conducted in the research that goes by the acronym STIRPAT (Stochastic Impacts by Regression on Population, Affluence and Technology). Analysis based on the STIRPAT model has led to a number of detailed statistical analyses of the relationships between affluence, consumption, and environmental impact (York, Rosa, and Dietz 2003). While these analyses have expanded our understanding of the influence of different levels of 
consumption on the environmental impact of different countries, it leaves the analysis of the social and economic forces behind consumption unexplained. As the Intergovernmental Panel on Climate Change (IPCC) has concluded, the IPAT model may be useful in organizing a discussion of the driving forces of environmental degradation; however, "affluence, population, and technological development should be considered neither as driving forces, nor generally independent from each other" (IPCC 2000:105). Thus in order to understand the social and economic forces that drive ecological degradation, it is necessary to move beyond a simple accounting framework and develop a more robust empirical model of the fundamental driving forces of the elements of the IPAT model. In this article, we focus on an analysis of the driving factors of personal consumption. It is the largest component of GDP and heavily influenced by a number of social and demographic factors.

\section{Determinants of Personal Consumption Levels}

The dominant approach to an examination of the determinants of personal consumption is through the use of economic analysis. At the center of this analysis is the notion of the "Consumption Function," which states that individual consumption rises in proportion to increases in real income (Denton 1992:7683; Legerbott 1996:39). Thus, the analysis centers around the impact of additional personal disposable income on consumption patterns. These analyses assume that personal consumption is based on maximization of consumer utility, or satisfaction, in a budget constrained situation (Deaton and Muellbauer 1980:359). The preferences that comprise consumer utility can be revealed through an analysis of spending patterns.

Individual consumption patterns are relatively stable over time due to three factors. First is the "State Adjustment Model" (Houthakker and Taylor 1970:923). Consumers develop buying habits. Repetitive and increasing consumption over time builds up a psychological stock of consumption preferences and leads to future expectations of consumption at the same or higher level. This habituates consumers to a pattern of increasing consumption over time. Thus, new products, when first introduced, are seen as luxuries. However, over time, the purchase of these new products becomes habituated, thereby becoming economic "necessities." This habituation of buying practices, leads to the second factor. Consumers will strive to maintain their consumption patterns, even when their personal disposable income declines. The use of individual assets or credit serves as a buffer in maintaining a given consumption pattern over time (Denton 1992). Finally, as Weber (1958) and Veblen (1953) have noted, consumption patterns are tightly linked to social status competition. Changes in consumption patterns can thus lead to loss of social status. Thus consumption patterns show a high degree of stability over time. 
In addition to Personal Disposable Income, there are a number of other factors theorized to influence the levels and nature of consumption. First is the level of inequality. Increased inequality is seen to reduce the amount of spending on basic necessities and increase spending in status consumption goods. Conversely, increased equality results in increased spending on basic necessities (Deaton and Muellbauer 1980:214-39). Population characteristics, specificically the age of the population and household formations, are other contributing factors to changes in individual consumption levels. Older age populations are seen to require greater resources and thus increased consumption levels. Likewise, much consumption takes place at the household level. Thus changes in the overall composition of households will impact personal consumption levels (IPCC 2000:112; Legerbott 1996:50-5).

What is missing in the economic analysis is an analysis of the role of culture in the creation and maintenance of consumer preferences. While economic analysis can reveal consumer preferences through spending patterns, they cannot examine the origins of these preferences, or what changes them. To move beyond an economic analysis of consumption, a more sociological perspective is needed. As noted by Douglas and colleagues (Douglas et al. 1998:259), "Human needs and wants are generated, articulated, and satisfied in an institutionalized feedback system. They do not appear from thin air." Thus, developing an informed understanding of the relationship between advertising and consumption requires that consumption be viewed, not as simply self-generated economic phenomena, but as integral outcome of the socialization of individuals due to their immersion in a consumer culture (Ewen 1976; Lears 1983).

\section{Advertising and Consumption}

Americans are inundated with advertisements. This has created a major industry. According to Advertising Age (2006) current spending on advertising in 2005 totaled over $\$ 271$ billion, yielding a per capita expenditure of $\$ 971$ in advertising expenditures for every individual in the United States. The impact of this advertising is well theorized in the notion of a consumer culture.

The origins of advertising lie in the desires of industrialists to enact a form of labor discipline. During the developmental stages of industrialism, social control of the labor force was a critical issue. In the face of rising labor tensions, industrialists arrived at the idea of using advertising to "superimpose new conceptions of individual attainment and community desire" (Ewen 1976:19). Through advertising, an ideology of human satisfaction through material possessions was developed. Based on this consumer ideology, industrialists satisfied their corporate need to distribute more goods, while simultaneously achieving social control over the labor force (Ewen 1976:19). As Marchland (1985:xviii, 43) notes, "In the process of selling specific products, advertisers also communicated broader assumptions 
about social values. Implicit value statements, passed along unconsciously as givens, usually carried an ideological bias toward 'system reinforcement'.... Advertisements therefore promulgated an 'integration propaganda' - that is, ideas and images that reinforce and intensify existing patterns and conceptions. So, rather than eradicate the working classes' resentment by improving their work lives, they [the industrialists] instead diverted the masses' frustrations by encouraging them to satisfy their needs for happiness through consumption."

In order for advertising to function in both its roles as sales producer and labor force discipline, it was critical to create status-oriented consumption. Advertising's function was to redefine basic human needs according to what the market could provide. One of the predominant advertising methods was to link improvement of an individual's self-image to solutions offered by the marketplace (Ewen 1976:39). In this sense, Schudson (1984) sees advertising as a form of "Capitalist Realism." Advertising provides individuals with a guide to living life by providing them with information regarding what their individual needs are and how certain commodities can satisfy them. In creating this worldview, advertising functions to define a reality that does not exist, but one that should be. It provides us with images of "life and lives worth emulating" (Schudson 1984:215) or the "good life" of a consumer society.

Increased exposure to advertising messages socializes individuals to satisfaction of needs and desires through market provided commodities. This leads to an increased dependency on finding commodified answers to our needs and desires (Ewen 1976:54), thus eclipsing an individual's ability to find pleasure or affect change outside the boundaries of the commodity system. According to Shove and Warde (2002:234-5), the end result is that "consumption then becomes more than just the pursuit of use-values or a claim to social prestige, for it is also deeply associated with the sense of self and personality. ... This 'production of the self' implies that the acquisition of goods and services has become central to personal psychological well-being."

Thus the creation and rise of the social construction of consumption preferences by the advertising industry helped to create a standard American style of mass consumption (Legerbott 1996:22-3). However, while there is an extensive historical and theoretical literature regarding the role of advertising and consumption, there are few robust empirical studies of its impact. In his review, Wilk (1997:111) notes that the role of advertising on actual consumer behavior is "still not clearly understood." Hence the NRC's call for quantitative studies into the role of advertising is needed to advance our understanding of the driving forces of individual consumption. As advertising is theorized to channel human desires into satisfaction in the marketplace, one would expect to see an increasing level of consumption in line with increased advertising expenditures. This leads to our first hypothesis: 
Hypothesis 1: Increased spending on advertising will increase individual consumption levels.

\section{Consumption by Type}

While advertising is theorized to have a significant impact on overall consumption, it is not at all clear that it will influence all consumption equally. There is a significant literature that argues that consumption varies by economic class and signifies social distinctions between different social groups. Those groups with higher income are better able to engage in status competition and thus, their purchases of more discretionary goods are impacted more by advertising (Dickens 2004:126-32). For example, Lutzenhiser (1997) shows that the determinants of household energy use, which include the type and extent of household appliances and overall housing size is largely an outcome of status competition.

It is well known that consumer demand for various goods levels off with increased income (Duchin 1997:64). In his analysis of consumer spending, Legerbott (1996) shows that basic consumption expenditures for food and clothing are maintained relative to expenditures for other items when there is an overall decrease in personal disposable income. From this literature, one would expect that advertising would have a greater impact on the consumption of highend luxury goods and less effect on the purchase of basic everyday commodities such as food and clothing. This leads to our second hypothesis:

Hypothesis 2: Advertising will have a greater impact on purchases of luxury goods versus basic necessities.

\section{Television Advertising and Consumption}

The vision of the industrialists of the 1920s to use advertising to fuel consumption marked the beginning of modern consumer culture. However, it was not until the 1950s postwar boom that commercial culture became truly widespread. Inequality drastically declined following World War II. This was coupled with a rapid postwar economic expansion. This rapidly expanded the ranks of the middle class and led to a rapid increase in personal disposable income. Building on this economic trend, advertisers coupled the patriotic spirit developed in World War II with consumption by promoting the "American" way of life as a materialist utopia. As Ewen (1976:211) notes, advertising promoted "an economic nationalism which signified the inviolate sanctity of the world of goods."

This rapid expansion of consumption was promoted by the development of the new advertising medium of television. Television was able to deliver product advertisements into people's homes and spread the vision of a "good life" on a mass scale. Following World War II, television use increased more than sevenfold 
between 1950 and 1955 and almost 11 -fold between 1950 and 2000 (U.S. Census Bureau 2003), representing "the fastest diffusion of a major technological innovation ever recorded" (Putnam 1996:42). As the number of televisions proliferated, so too did the amount of time people spent consuming its messages. The average household went from an average of 4.72 hours per day watching television in 1950 to 7.62 hours per day in 2000 .

These hours spent watching television has a large impact on consumer demand. This large time investment translates into mass acceptance of the lifestyles featured in TV shows and for the advertised products that sponsor the shows (Kubey and Csikszentmihalyi 1990). In fact, the demand for access to these audiences is in such high demand that advertisers bid for access to them as if they were commodities themselves (Croteau and Hoynes 2000).

Television's pairing with advertising was no coincidence. Advertising has always been the lifeblood of broadcasting. Schiller (1969:20) noted that "no sudden coup captured broadcasting for commerce and turned American radiotelevision programming into the soul-destroying wasteland it is." Its development into the mainstream was controlled at all times by the market system that surrounded it. The product advertisers exercise substantial control of the development of television programming. The end result of this control is that television has simply become a "vehicle for creating popular demand within an economy greatly dependent on mass consumption for its vitality" (MacDonald 1990:257).

Reinforcing television's affect on people's consumption habits through its concerted advertising messages is its ability to commoditize individual behavior and mold an entire worldview simply by its characteristics. As this new technology became a societal mainstay, social norms consequently changed in order to suit the way that this technology operates. As a result, it changed how humans experienced the world and how they interacted with one another (McLuhan 1964:130).

First, the development of television cultivated a passive dependency on television for knowledge of the world and social standards. Beginning in the late 1950 s, researchers argued that television watching was inherently a passive activity (Meyersohn 1957). When television exposes the viewer to outside events, the events come to the individual as a presented story in a ready made form. As a result, Anders (1956:362) argued that "we are no longer 'in the world,' but only listless, passive consumers of the world." As research on television expanded, it was linked to television-induced passivity and a dulled human sensibility, with a dim awareness of the world outside of what is presented on television (Mander 1977). This reality takes the form of a "world as image on a screen" (Anders 1956:359).

In addition to enhancing affinities for passive dependence on television as the arbiter of reality and of social standards, the medium of television itself contributes to both social isolation and possessive individualism. Because 
television watching is an individual activity carried out in the privacy of one's home, it enables the advertiser to define the nature of the good life in the mass purchase of individual commodities. So, unlike the theatre experience where the masses consume one show in a group, the experience of watching television allows viewers to individually satisfy their desires based on a wide choice of shows and, of course, the purchase of commodities advertised for the target audience of each show (Anders 1956). This leads to the greater individualization of society and the linking of individual identities to specific consumption life styles. Instead of a collective society, television contributes to the creation of a society composed of an aggregate of "mass hermits" instead of a social community. This social isolation leads to the creation of narcissistic personalities manipulated through product advertising (Beck 1995:40, 59; Habermas 1987). Taken together, increased social isolation, possessive individualism and dependence on television reinforce a commodity-mindset and worldview that advertising seeks to promote. Therefore, we would expect TV advertising cues to have a very strong impact on consumption levels in comparison with other media. This leads to our third hypothesis:

Hypothesis 3: Television advertising will exert a strong influence on consumption levels in comparison to other forms of advertising.

\section{Variables and Analysis Procedures}

To test the three hypotheses developed in the previous section, we compiled data on the following items:

\section{Dependent Variable}

The dependent variable is personal consumption expenditures per capita, both total and in specific categories. Data were compiled from two sources. For the time period 1900-1929, Table A1 in Legerbott (1996:179) was used. For the time period 1930-2000, the Bureau of Economic Analysis (1930-2005) Table 2.3.5 (Personal Consumption Expenditures by Major Type of Product) was used. All expenditures were adjusted to $\$ 2000$. These amounts were then divided by the total population to develop per capita individual personal consumption.

We recognize that the use of personal consumption expenditures as a measure of consumption is somewhat problematic. Consumption is calculated by multiplying the frequency of use of an item by its price. So this is not an actual measure of consumption. Price increases can result in decreased overall use of an item, while its overall dollar value of consumption increases. Despite this limitation, the use of consumption expenditures (in the form of GDP) is the standard measure within a large number of empirical analyses of consumption (York, Rosa, and Dietz 2003; Mazur 1994; Shi 2003; Waggoner and Ausubel 2002). So while this analysis fits within the standard economic and sociological 
practices, the use of the dollar value of consumption as the sole measure of personal consumption is limited in its validity. However, there is no other available measure of personal consumption at this time.

\section{Independent Variable}

The independent variable is Per Capita Advertising Expenditures in the United States. Advertising expenditures - both total and by specific products on television-were compiled from the Statistical Abstract of the United States and from the annual report in Advertising Age. All expenditures were adjusted to $\$ 2000$ and divided by the population to develop a per capita measure of advertising expenditures.

\section{Control Variables}

A number of control variables were used in models to control for the effects of three types of variables:

Population Characteristics. As discussed earlier, it has been hypothesized that changes in the age and household characteristics of the U.S. population would impact consumption levels. To account for the hypothesized effect of these variables, two control variables were added to the model: (1) Population Median Age and (2) Average Household Size. Both variables were extracted from the Statistical Abstract of the United States.

Income Inequality. To account for the hypothesized impact of income inequality on consumption, the Family Gini coefficient was added to the model. This was derived from the Statistical Abstract of the United States.

Disposable Personal Income. To control for changes in personal disposable income, data were compiled from two sources. For the time period 1900-1929, Table A6 in Legerbott (1996:179) was used. For the time period 1930-2000, the Bureau of Economic Analysis (1930-2005) Table 2.1 (Personal Income and Its Disposition) was used. All expenditures were adjusted to $\$ 2000$. These values were then divided by the total population to arrive at Disposable Personal Income per Capita.

\section{Analysis Procedures}

All of the independent and control variables are highly trended over time. Because of this, significant autocorrelation effects were noted using standard multivariate analysis techniques. To control for autocorrelation effects, the data was transformed into its first differences. This allows a trended and nonstationary variable to be treated as a stationary variable (Dickey, Bell, and Miller 1986). 
Second, the analysis of the data was conducted through a time series ordinary least square (OLS) analysis with continuous variables. This model takes the form $Y_{t}=a+A R[1]_{t}++b 1 X 1_{t}+\ldots b n X n_{t}+e_{t} \ldots$ Autocorrelation was controlled for by use of the autoregression variable $A R[1]_{t}$, calculated using exact maximumlikelihood Prais-Winston procedure. In combination, the differencing and autoregressive statistical procedure resulted in excellent control of autocorrelation effects as indicated by the Durbin-Watson statistic. A comparison with the Durbin-Watson significance tables (SPSS 2004:178-97) shows that there was no statistically significant autocorrelation present in any of the final models.

\section{Results}

We present results from the analysis in three different models.

\section{Model 1}

The first model tests the relationship between advertising expenditures and personal consumption levels. The results of the time series analysis are shown in Table 1. The first test only included disposable personal income and advertising expenditures. Both of these variables showed a strong influence on overall consumption. In the second and third tests, population median age and average household size were entered into the equation. Neither of the population characteristics variables had any significance. In the fourth test, the Gini coefficient was added. This also had no statistical significance. Finally, in the fifth test, the independent and control variables were entered into the equation. This did not result in any statistically significant change in the results of the analysis.

These results clearly show that advertising expenditures have a significant impact on consumption levels and that, together, disposable personal income and advertising explain a great deal of the variance in overall consumption (R-square $=.655)$. The median age of the population has no effect on personal consumption levels. One possible reason for this is that the medical expenditures on the elderly population are funded from government old age insurance programs and are counted as government consumption. Household size also does not impact overall consumption levels. Finally, there is no identifiable impact of inequality on the overall levels of personal consumption.

\section{Model 2}

To further examine the relationship between personal consumption and key determinates, a second model was run. Personal consumption expenditures vary significantly by type of consumption. Specifically, it was hypothesized that advertising would have a greater impact on purchases of luxury goods vs. basic necessities. To test this hypothesis, a series of tests were conducted using time series analysis techniques. The results are shown in Table 2. 
Table 1

Multilevel Models Predicting Total Personal Consumption per Capita Levels in the United States, 1900-2000

\begin{tabular}{|c|c|c|c|c|c|}
\hline Variables & Model 1 & Model 2 & Model 3 & Model 4 & Model 5 \\
\hline Disposable personal income per capita & $\begin{array}{l}.405^{* * *} \\
(.052)\end{array}$ & $\begin{array}{l}.406^{* * * *} \\
(.051)\end{array}$ & $\begin{array}{l}.413 * * * \\
(.052)\end{array}$ & $\begin{array}{l}.426^{* * *} \\
(.061)\end{array}$ & $\begin{array}{l}.438 * * * \\
(.060)\end{array}$ \\
\hline Advertising expenditures per capita & $\begin{array}{l}5.432 * * * \\
(.890)\end{array}$ & $\begin{array}{l}5.330 * * * \\
(.897)\end{array}$ & $\begin{array}{l}5.533 * * * \\
(.894)\end{array}$ & $\begin{array}{l}5.501 * * * \\
(.954)\end{array}$ & $\begin{array}{l}5.530 * * * \\
(.959)\end{array}$ \\
\hline Population median age & & $\begin{array}{c}768.670 \\
(157.202)\end{array}$ & & & $\begin{array}{c}164.287 \\
(153.211)\end{array}$ \\
\hline Average household size & & & $\begin{array}{c}697.052 \\
(799.034)\end{array}$ & & $\begin{array}{l}1015.572 \\
(847.999)\end{array}$ \\
\hline Gini coefficient & & & & $\begin{array}{c}635.960 \\
(683.130)\end{array}$ & $\begin{array}{c}247.028 \\
(127.537)\end{array}$ \\
\hline Rho (AR1) & $\begin{array}{l}.318 * * \\
(.097)\end{array}$ & $\begin{array}{l}.307 * * \\
(.098)\end{array}$ & $\begin{array}{l}.295 * * \\
(.098)\end{array}$ & $\begin{array}{l}.287^{* *} \\
(.106)\end{array}$ & $\begin{array}{c}.235^{*} \\
(.109)\end{array}$ \\
\hline$N$ & 101 & 101 & 101 & 86 & 86 \\
\hline $\begin{array}{l}\text { Durbin-Watson } \\
\text { R-square }\end{array}$ & $\begin{array}{r}1.989 \\
.655\end{array}$ & $\begin{array}{r}1.986 \\
.662\end{array}$ & $\begin{array}{r}1.996 \\
.663\end{array}$ & $\begin{array}{r}1.974 \\
.662\end{array}$ & $\begin{array}{r}1.978 \\
.685\end{array}$ \\
\hline
\end{tabular}

Note: Data shown as coefficients (standard errors in parentheses).

$* P<.05 ; * * P<.01 ; * * * P<.001$ (two-tailed tests).

Prais-Winsten estimation method used. Time series regression based on first difference data transformation of all variables. 
Table 2

Multilevel Models Predicting Personal Consumption Levels per Capita by Type in the United States, 1900-2000

\begin{tabular}{|c|c|c|c|c|c|}
\hline Variables & $\begin{array}{c}\text { Model } 1 \\
\text { Total } \\
\text { consumption }\end{array}$ & $\begin{array}{c}\text { Model } 2 \\
\text { Food } \\
\text { consumption }\end{array}$ & $\begin{array}{c}\text { Model } 3 \\
\text { Clothing } \\
\text { consumption }\end{array}$ & $\begin{array}{c}\text { Model } 4 \\
\text { Housing } \\
\text { appliances } \\
\text { and supplies }\end{array}$ & $\begin{array}{c}\text { Model } 5 \\
\text { Automobile } \\
\text { purchase and } \\
\text { operation }\end{array}$ \\
\hline Disposable personal income per capita & $\begin{array}{l}.438 * * * \\
(.060)\end{array}$ & $\begin{array}{l}.123 * * * \\
(.027)\end{array}$ & $\begin{array}{l}.067 * * * \\
(.013)\end{array}$ & $\begin{array}{l}.020 \\
(.011)\end{array}$ & $\begin{array}{l}-.032 \\
(.030)\end{array}$ \\
\hline Advertising expenditures per capita & $\begin{array}{l}5.530 * * * \\
(.959)\end{array}$ & $\begin{array}{r}-.086 \\
.420\end{array}$ & $\begin{array}{c}.257 \\
(.201)\end{array}$ & $\begin{array}{l}1.104 * * * \\
.181\end{array}$ & $\begin{array}{l}2.845^{* * * *} \\
(.509)\end{array}$ \\
\hline Population median age & $\begin{array}{c}164.287 \\
(153.211)\end{array}$ & $\begin{array}{r}-32.519 \\
79.799\end{array}$ & $\begin{array}{l}-1.700 \\
(29.499)\end{array}$ & $\begin{array}{c}-1.972 \\
(26.676)\end{array}$ & $\begin{array}{c}-21.879 \\
(56.906)\end{array}$ \\
\hline Average household size & $\begin{array}{l}1015.572 \\
(847.999)\end{array}$ & $\begin{array}{c}316.906 \\
(378.438)\end{array}$ & $\begin{array}{c}136.088 \\
(175.865)\end{array}$ & $\begin{array}{c}-34.453 \\
(158.377)\end{array}$ & $\begin{array}{c}-434.653 \\
(418.398)\end{array}$ \\
\hline Gini coefficient & $\begin{array}{c}247.028 \\
(127.537)\end{array}$ & $\begin{array}{c}-1193.403 * * * \\
(295.870)\end{array}$ & $\begin{array}{c}-461.076^{* *} \\
(145.672)\end{array}$ & $\begin{array}{c}-32.551 \\
(131.011)\end{array}$ & $\begin{array}{c}163.314 \\
(378.155)\end{array}$ \\
\hline Rho (AR1) & $\begin{array}{c}.235^{*} \\
(.109)\end{array}$ & $\begin{array}{l}.381 * * * \\
(.102)\end{array}$ & $\begin{array}{l}.143 \\
(.112)\end{array}$ & $\begin{array}{l}.149 \\
(.113)\end{array}$ & $\begin{array}{l}-.341 * * \\
(.106)\end{array}$ \\
\hline$N$ & 86 & 86 & 86 & 86 & 86 \\
\hline Durbin-Watson & 1.978 & 1.943 & 1.883 & 1.882 & 2.123 \\
\hline R-square & .685 & .437 & .525 & .471 & .311 \\
\hline
\end{tabular}

Note: Data shown as coefficients (standard errors in parentheses).

$* P<.05 ; * * P<.01 ; * * * P<.001$ (two-tailed tests).

Prais-Winsten estimation method used. Time series regression based on first difference data transformation of all variables. 
The first model in column one is identical to the final model in Table 1. This shows the overall impact of the independent and control variables on total personal consumption per capita. This is included for comparison purposes.

Column two shows the results of the analysis examining total per capita food consumption. In this model, advertising has no statistical effect. However, disposable personal income and income inequality (as measured by the Gini coefficient) show that food consumption is positively related to increases in personal disposable income and negatively related to increases in income inequality. Column three shows the analysis of the determinants of clothing consumption. Here the result is identical to that of food consumption. As inequality increases and personal disposable income decreases, less is spent on these basic commodities. This is in line with the standard economic analyses of the impacts of income inequality and income levels on consumption. Neither food nor clothing expenditures are impacted by advertising expenditures.

A much different pattern is shown in the analysis of the determinants of personal consumption expenditures for housing appliances and for automobiles. The results of these analyses are shown in columns four and five. Here the only variable that has an impact is advertising expenditures. Because automobiles and household appliances usually serve all the members of a household, it is surprising to see that the number of households does not exert a significant influence on these types of consumption. Nor does personal disposable income impact on the overall level of consumption of household appliances or automobiles. This indicates the impact of the common practice of buying these items on credit or through the use of savings. This analysis shows that personal consumption expenditures are the result of a complex series of variables, each operating on a specific type of purchase. So while advertising has an impact on overall consumption, its impacts are concentrated in specific types of expenditures.

\section{Model 3}

The final analysis examined the relationship between television advertising and consumption. Because of its pervasive effect and high levels of exposure, it was hypothesized that television advertising would be a highly effective form of advertising. To test this hypothesis, a series of five tests were conducted. The results of this analysis are shown in Table 3.

Since television came into existence in 1950, the first model (in column one) examined the impact of advertising on total per capita individual consumption, using the previously verified variables of total advertising expenditures per capita and disposable income per capita. To these two variables, a dummy variable for the post-1949 time period was included. As this analysis shows, advertising was more effective in the time period when television was in use. This suggests 
Table 3

Multilevel Models Predicting Personal Consumption Levels per Capita by Type and Television Advertising Expenditures by Type in the United States, 1950-2000

\begin{tabular}{|c|c|c|c|c|c|c|c|}
\hline Variables & $\begin{array}{c}\text { Model } 1 \\
\text { Total } \\
\text { consumption }\end{array}$ & $\begin{array}{c}\text { Model } 2 \\
\text { Total } \\
\text { consumption } \\
\text { after } 1949\end{array}$ & $\begin{array}{c}\text { Model } 3 \\
\text { Total } \\
\text { consumption }\end{array}$ & $\begin{array}{c}\text { Model } 4 \\
\text { Food } \\
\text { consumption }\end{array}$ & $\begin{array}{l}\text { Model } 5 \\
\text { Clothing } \\
\text { consumption }\end{array}$ & $\begin{array}{c}\text { Model } 6 \\
\text { Housing } \\
\text { appliances } \\
\text { and supplies } \\
\text { consumption }\end{array}$ & $\begin{array}{c}\text { Model } 6 \\
\text { Automobile } \\
\text { purchase and } \\
\text { operation } \\
\text { consumption }\end{array}$ \\
\hline $\begin{array}{l}\text { Disposable personal } \\
\text { income per capita }\end{array}$ & $\begin{array}{l}.382 * * * \\
(.052)\end{array}$ & $\begin{array}{l}.562 * * * \\
(.099)\end{array}$ & $\begin{array}{l}.831 * * * \\
(.088)\end{array}$ & $\begin{array}{l}.080 * * \\
(.024)\end{array}$ & $\begin{array}{l}.071 * * * \\
(.011)\end{array}$ & $\begin{array}{l}.064 * * * \\
(.015)\end{array}$ & $\begin{array}{l}.148 * * * \\
(.037)\end{array}$ \\
\hline $\begin{array}{l}\text { Advertising - total } \\
\text { expenditures per capita }\end{array}$ & $\begin{array}{l}5.326 * * * \\
(.877)\end{array}$ & $\begin{array}{l}5.126^{* * *} \\
(1.319)\end{array}$ & & & & & \\
\hline Year $\geq 1950$ & $\begin{array}{c}92.668 * \\
(40.884)\end{array}$ & & & & & & \\
\hline $\begin{array}{l}\text { TV advertising - total } \\
\text { expenditures per capita }\end{array}$ & & & $\begin{array}{l}10.604 \\
(9.615)\end{array}$ & & & & \\
\hline $\begin{array}{l}\text { TV advertising for food- } \\
\text { expenditures per capita }\end{array}$ & & & & $\begin{array}{c}.142 \\
(3.785)\end{array}$ & & & \\
\hline $\begin{array}{l}\text { TV advertising for } \\
\text { clothing-expenditures } \\
\text { per capita }\end{array}$ & & & & & $\begin{array}{c}21.131 \\
(14.886)\end{array}$ & & \\
\hline $\begin{array}{l}\text { TV advertising for } \\
\text { housing appliance- } \\
\text { expenditures } \\
\text { per capita }\end{array}$ & & & & & & $\begin{array}{c}6.953 * \\
(3.288)\end{array}$ & \\
\hline
\end{tabular}


Table 3

(Continued)

\begin{tabular}{|c|c|c|c|c|c|c|c|}
\hline Variables & $\begin{array}{c}\text { Model } 1 \\
\text { Total } \\
\text { consumption }\end{array}$ & $\begin{array}{c}\text { Model } 2 \\
\text { Total } \\
\text { consumption } \\
\text { after } 1949\end{array}$ & $\begin{array}{c}\text { Model } 3 \\
\text { Total } \\
\text { consumption }\end{array}$ & $\begin{array}{c}\text { Model } 4 \\
\text { Food } \\
\text { consumption }\end{array}$ & $\begin{array}{c}\text { Model } 5 \\
\text { Clothing } \\
\text { consumption }\end{array}$ & $\begin{array}{c}\text { Model } 6 \\
\text { Housing } \\
\text { appliances } \\
\text { and supplies } \\
\text { consumption }\end{array}$ & $\begin{array}{c}\text { Model } 6 \\
\text { Automobile } \\
\text { purchase and } \\
\text { operation } \\
\text { consumption }\end{array}$ \\
\hline $\begin{array}{l}\text { TV advertising for } \\
\text { automobile- } \\
\text { expenditures } \\
\text { per capita }\end{array}$ & & & & & & & $\begin{array}{l}11.747 \\
(6.018)\end{array}$ \\
\hline Rho (AR1) & $\begin{array}{l}.269 * * \\
(.099)\end{array}$ & $\begin{array}{l}-.045 \\
(.146)\end{array}$ & $\begin{array}{l}-.152 \\
(.146)\end{array}$ & $\begin{array}{c}.233 \\
(.143)\end{array}$ & $\begin{array}{c}.055 \\
(.147)\end{array}$ & $\begin{array}{l}.215 \\
(.144)\end{array}$ & $\begin{array}{l}-.072 \\
(.147)\end{array}$ \\
\hline$N$ & 101 & 51 & 51 & 51 & 51 & 51 & 51 \\
\hline Durbin-Watson & 1.964 & 1.936 & 1.956 & 1.918 & 1.913 & 1.894 & 1.972 \\
\hline R-square & .683 & .749 & .716 & .204 & .475 & .365 & .373 \\
\hline
\end{tabular}

Note: Data shown as coefficients (standard errors in parentheses).

$* P<.05 ; * * P<.01 ; * * * P<.001$ (two-tailed tests).

Prais-Winsten estimation method used. Time series regression based on first difference data transformation of all variables. Television advertising expenditures based on total network advertising expenses by category. 
that the development of television may have played a role in increasing the effectiveness of advertising.

To further examine the impact of television, a series of analyses were carried out in columns two through seven. These analyses were limited to the post-1949 time period in which television advertising existed. Column two shows a comparison model in which personal disposable income and total advertising expenditures were used to examine the impact of these two variables on total personal consumption. This analysis replicates the already developed analysis previously presented. Columns three then show an analysis of the impacts of both personal disposable income and television advertising per capita on total personal consumption per capita. This analysis does not show any significant statistical effect of television advertising on personal consumption. In columns four through seven, television advertising expenditures for specific products were used to examine consumption of the advertised product. In all cases, personal disposable income has a significant impact. However, in only one case - household appliances - did television advertising have a significant impact. These results are unexpected, given the strong theoretical development of the impact of television advertising on personal consumption.

\section{Conclusion}

As we hypothesized in this article, advertising plays a significant role in the expansion of personal consumption. However, this role is not universal. This analysis shows that the primary determinants of personal consumption are personal disposable income and advertising expenditures. In testing our first hypothesis, that increased spending on advertising will increase individual consumption levels, advertising was found to have a significant impact on consumption levels, as was also true for personal disposable income.

Our second hypothesis, that determinants of consumption will vary by type of consumption, was also proven correct. Most importantly, we established that personal disposable income has a significant impact on the consumption of basic commodities, such as food and clothing. However, it does not have a significant impact on consumption of luxury goods, such as household appliances and automobiles. The reverse is true for the impact of advertising. It has little effect on basic commodities, but a large effect on luxury goods. So, while advertising does have a significant impact on overall consumption, its impacts are concentrated.

Surprisingly, the impact of television advertising alone is nearly statistically insignificant. This analysis presents a serious question to the theoretical assumptions of the literature on the consumption effects of television alone. More likely, television advertising acts in concert with other advertising media to achieve an overall impact on personal consumption. This analysis points to 
the need for further testing of the theoretical literature regarding the impact of television on individual consumption.

Finally, this analysis shows that to fully understand the driving forces of global environmental change, there is a need to move beyond the IPAT/STIRPAT models and probe into the social and economic determinants that result in increased environmental impacts. In this article, we have examined only the determinants of personal consumption expenditures. Left unexamined are the determinants of government consumption and business investment expenditures. All three of these dimensions of consumption need to be investigated for a robust understanding of what drives total consumption.

The results of our analysis highlight several important areas for future research. First, it is now evident that there is a link existing between advertising and consumption. The next research step would be to establish the links between the drivers of consumption, the increased use of natural resources, and the concomitant increased levels of environmental degradation. While this link can be established theoretically, there is a vital need to test these relationships empirically. Finally, this analysis shows that there is a significant role to be played by sociological analysis in developing an understanding of the driving forces of global environmental change. Future analyses of the driving forces of global environmental change needs an expanded framework capable of moving beyond a single focus on economic analysis and toward the incorporation of social and cultural factors.

\section{REFERENCES}

Advertising Age. 2006. "100 Leading National Advertisers." Advertising Age June 26, 2006.

Anders, Gunther. 1956. "The Phantom World of TV." Pp. 358-67 in Mass Culture: the Popular Arts in America, edited by Bernard Rosenburg and David White. New York: Free Press.

Beck, Ulrich. 1995. Ecological Enlightenment: Essays on the Politics of the Risk Society. New York: Humanity Books.

Bureau of Economic Analysis. 1930-2005. "Income and Expenditures. Table 2.1. Personal Income and Its Disposition: Bureau of Economic Analysis." Retrieved May 24, 2006. <http:// www.bea.gov/national/nipaweb/SelectTable.asp>.

Chertow, Marion. 2001. "The IPAT Equation and Its Variants: Changing Views of Technology and Environmental Impact." Journal of Industrial Ecology 4:13-29.

Chivian, E., M. McCally, H. Hu, and A. Haines, eds. 1993. Critical Condition. Cambridge, MA: MIT Press.

Croteau, D. and W. Hoynes. 2000. Media/Society: Industries, Images, and Audiences. 2nd ed. Thousand Oaks, CA: Pine Forge Press.

Deaton, Angus and John Muellbauer. 1980. Economics and Consumer Behavior. New York: Cambridge University Press.

Denton, Angus. 1992. Understanding Consumption. New York: Oxford University Press. 
Dickens, Peter. 2004. Society and Nature. Malden, MA: Polity Press.

Dickey, D. A., W. R. Bell, and R. B. Miller. 1986. "Unit Roots in Time Series Models: Tests and Implications." The American Statistician 40(1):12-26.

Dietz, Thomas and Eugene A. Rosa. 1994. "Rethinking the Environmental Impacts of Population, Affluence and Technology." Human Ecology Review 1(2):277-300.

Douglas, M. D. Gasper, S. Ney, and M. Thompson. 1998. "Human Needs and Wants." Pp. 195-263 in Human Choice and Climate Change, edited by S. Rayner and E. Malone. Columbus, $\mathrm{OH}$ : Battelle Press.

Duchin, Faye. 1997. "Structural Economics: A Strategy for Analyzing the Implications of Consumption." Pp. 63-72 in Environmentally Significant Consumption: Research Directions, edited by P. Stern, T. Dietz, V. W. Ruttan, R. H. Socolow, and J. L. Sweeney. Washington, DC: National Academy Press.

Ehrlich, Paul R. and John P. Holdren. 1971. "Impact of Population Growth.” Science 171:1212-17.

Ewen, Stuart. 1976. Captains of Consciousness: Advertising and the Social Roots of the Consumer Culture. New York: McGraw-Hill.

Galbraith, John Kenneth. 1958. "How Much Should a Country Consume?" Pp. 89-99 in Perspectives on Conservation: Essays on America's Natural Resources, edited by Henry Jarrett. Baltimore, MD: Johns Hopkins University Press.

Habermas, Jürgen. 1987. The Theory of Communicative Action, vol. 2, Lifeworld and System: A Critique of Functionalist Reason. Boston, MA: Beacon Press.

Hansen, J. E. 2005. "Is There Still Time to Avoid 'Dangerous Anthropogenic Interference' With Global Climate?" Paper presented at the American Geophysical Union Conference, San Francisco, CA, December 6.

Houthakker, H. S. and L. D. Taylor. 1970. Consumer Demand in the United States: Analyses and Projections. Cambridge, MA: Harvard University Press.

Intergovernmental Panel on Climate Change (IPCC). 2000. Special Report on Emissions Scenarios. New York: Cambridge University Press.

Kubey, R. and M. Csikszentmihalyi. 1990. "Television and the Restructuring of Experience." Pp. 260-2 in The Consumer Society: Frontier Issues in Economic Thought, edited by N. Goodwin, F. Ackerman, and D. Kiron. Washington, DC: Island Press.

Leafs, T. 1983. "From Salvation to Self-Realization: Adverting and the Therapeutic Roots of the Consumer Culture, 1880-1930." Pp. 1-38 in The Culture of Consumption Critical Essays in American History, 1880-1980, edited by R. Fox and T. Leafs. New York: Pantheon Books.

Lebergott, Stanley. 1996. Consumer Expenditures: New Measures \& Old Motives. Princeton, NJ: Princeton University Press.

Lutzenhiser, Loren. 1997. "Social Structure, Culture, and Technology: Modeling the Driving Forces of Household Energy Consumption.” Pp. 77-91 in Environmentally Significant Consumption: Research Directions, edited by P. Stern, T. Dietz, V. W. Ruttan, R. H. Socolow, and J. L. Sweeney. Washington, DC: National Academy Press.

MacDonald, J. Fred. 1990. "The Emergence of American Television: The Formative Years." Pp. 257-9 in The Consumer Society: Frontier Issues in Economic Thought, edited by N. Goodwin, F. Ackerman, and D. Kiron. Washington, DC: Island Press.

Mander, Jerry. 1977. Four Arguments for the Elimination of Television. New York: Perennial.

Manno, Jack P. 1999. Privileged Goods: Commoditization and Its Impact on Environment and Society. New York: Lewis Publishers.

Marchand, Roland. 1985. Advertising the American Dream: Making Way for Modernity. Berkeley, CA: University of California Press.

Mazur, Allan. 1994. "How Does Population Growth Contribute to Rising Energy Consumption in America?" Population and Environment 15:371-8. 
McCally, M. 2002. "Social Policy and Social Movements." Annals of the American Academy of Political and Social Science 584:145.

McLuhan, Marshall. 1964. "The Medium Is the Message." Pp. 129-38 in Media and Cultural Studies: Keyworks, edited by M. Durhan and D. Kellner. Malden, MA: Blackwell Publishing.

Meyersohn, Rolf B. 1957. "Social Research in Television.” Pp. 345-55 in Mass Culture: The Popular Arts in America, edited by Bernard Rosenburg and David White. New York: Free Press.

National Research Council (NRC). 1999. Global Environmental Change: Research Pathways for the Next Decade. Washington, DC: National Academy Press.

Ordway, Samuel H. Jr. 1953. Resources and the American Dream. New York: Ronald Press Company.

Putnam, Robert D. 1996. "The Strange Disappearance of Civic America." American Prospect 24:3448.

Schiller, Herbert I. 1969. Mass Communications and American Empire. Boston, MA: Beacon Press.

Schudson, Michael. 1984. Advertising, the Uneasy Persuasion: Its Dubious Impact on American Society. New York: Basic Books.

Shi, Anqing. 2003. "The Impact of Population Pressure on Global Carbon Dioxide Emissions: Evidence from Pooled Cross-Country Data." Ecological Economics. 44:24-42.

Shove, Elizabeth and Alan Warde. 2002. "Inconspicuous Consumption: The Sociology of Consumption, Lifestyles, and the Environment." Pp. 230-51 in Sociological Theory and the Environment: Classical Foundations, Contemporary Insights, edited by R. Dunlap, F. Buttel, P. Dickens, P. Gijswijt, and A. Gijswijt. New York: Rowman and Littlefield.

Statistical Package for the Social Sciences (SPSS). 2004. SPSS Trends 13.0. Chicago, IL: SPSS Inc.

U.S. Census Bureau Series. 2003. Statistical Abstract of the United States. Washington, DC: U.S. Government Press.

Veblen, Thorstein. 1953. The Theory of the Leisure Class. New York: New American Library.

Vitousek, P., H. Mooney, J. Lubchenco, and J. Melillo. 1997. "Human Domination of Earth's Ecosystems." Science 277:494-9.

Wackernagel, M. and W. Rees. 1996. Our Ecological Footprint. Gabriola Island, BC: New Society Publishers.

Waggoner, Paul E. and Jesse H. Ausubel. 2002. "A Framework for Sustainability Science: A Renovated IPAT Identity." Proceedings of the National Academy of Sciences 99:7860-5.

Weber, Max. 1958. The Protestant Ethic and the Spirit of Capitalism. New York: Charles Scribner's Sons.

Wilk, Richard R. 1997. "Emulation and Global Consumerism.” Pp. 110-15 in Environmentally Significant Consumption: Research Directions, edited by P. Stern, T. Dietz, V. W. Ruttan, R. H. Socolow, and J. L. Sweeney. Washington, DC: National Academy Press.

York, R., E. Rosa, and T. Dietz. 2003 "Footprints on the Earth." American Sociological Review 68:279-300. 